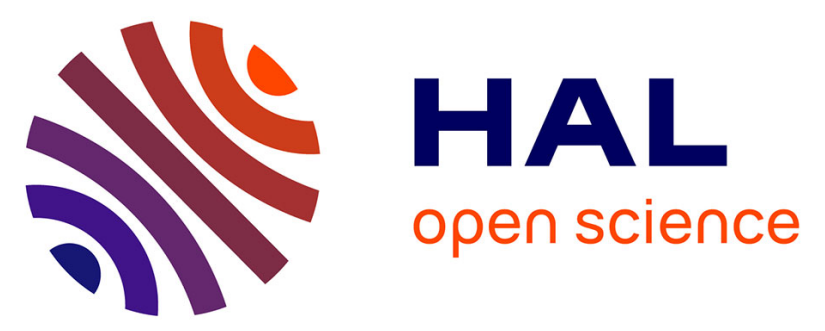

\title{
Regiospecific Inverse-Electron-Demand Diels-Alder Reaction of Simultaneously Electrogenerated Diene and Dienophile: An Expeditious Route to Polyfunctionalized 1,4-Benzoxazine Derivatives
}

\author{
Martine Largeron, Anne Neudorffer, Marc Vuilhorgne, Estelle Blattes, \\ Maurice-Bernard Fleury
}

\section{To cite this version:}

Martine Largeron, Anne Neudorffer, Marc Vuilhorgne, Estelle Blattes, Maurice-Bernard Fleury. Regiospecific Inverse-Electron-Demand Diels-Alder Reaction of Simultaneously Electrogenerated Diene and Dienophile: An Expeditious Route to Polyfunctionalized 1,4-Benzoxazine Derivatives. Angewandte Chemie International Edition, 2002, 41 (5), pp.824. 10.1002/15213773(20020301)41:53.0.co;2-z . hal-02385108

\author{
HAL Id: hal-02385108 \\ https://hal.science/hal-02385108
}

Submitted on 5 Feb 2021

HAL is a multi-disciplinary open access archive for the deposit and dissemination of scientific research documents, whether they are published or not. The documents may come from teaching and research institutions in France or abroad, or from public or private research centers.
L'archive ouverte pluridisciplinaire HAL, est destinée au dépôt et à la diffusion de documents scientifiques de niveau recherche, publiés ou non, émanant des établissements d'enseignement et de recherche français ou étrangers, des laboratoires publics ou privés. 
Regiospecific Inverse Electron Demand Diels-Alder Reaction of Simultaneously Electrogenerated Diene and Dienophile. An Expeditious Route to New Polyfunctionalized 1,4-Benzoxazine Derivatives.

Martine Largeron*, Anne Neudorffer, Marc Vuilhorgne, Estelle Blattes and Maurice-Bernard Fleury.

[*] Prof. M.-B. Fleury, Dr. M. Largeron, Dr. A. Neudorffer, Dr. M. Vuilhorgne $[+]$, E. Blattes

Laboratoire de Chimie Analytique et Electrochimie, UMR 8638 CNRS - Université René Descartes

Faculté des Sciences Pharmaceutiques et Biologiques 4, Avenue de l'Observatoire, 75270 Paris Cedex 06 (France) Fax : $01 \quad 43 \quad 2905 \quad 92$

E-mail : largeron@pharmacie.univ-paris5.fr

[+] Aventis Pharma

Centre de Recherche de Vitry-Alfortville 13, quai Jules Guesde 94403 Vitry-sur-Seine (France)

Quinonoid systems are powerful intermediates for organic synthesis and constitute potential precursors to numerous naturally occurring substances.[1] However, synthesis of quinonoid entities, particularly o-quinones and o-azaquinones which are usually unstable and very prone to polymerization, is not highly developed.[2] The facile generation of o-quinone-type structures from electrochemical oxidation of related o-quinols, and their well-known ability to react with nucleophiles, [3] prompted 
us to investigate the reaction of highly reactive electrogenerated o-quinone species with amino alcohols. We have thus recently described the one-pot electrochemical synthesis of substituted 1,4-benzoxazine derivatives, which constitute a novel class of potent neuroprotective agents. [4]

We have also revealed a new mode of reactivity of these quinonoid systems, [5] in which electrogenerated 3,4aza-quinone $\mathbf{1}_{\mathbf{o x}}$ (Scheme 1 ) acts as an efficient catalyst for the autorecycling oxidation of benzylamine, in a way reminiscent of that reported for amine oxidoreductase model cofactors; the reaction efficiency reached 64 turnovers. Through electrochemical investigations, we have established that the deamination mechanism of benzylamine by our model cofactor $\mathbf{1}_{\mathbf{o x}}$ was akin to the transamination reaction of pyridoxal phosphate with amino acids. The catalytic cycle produced the reduced catalyst $\mathbf{1}_{\text {red }}$ and N-benzylidenebenzylamine as the product of benzylamine oxidation (Scheme 1). The potent reactivity of $\mathbf{1}_{\text {ox }}$ was further extended to unactivated primary aliphatic amines. In several cases (isopentylamine, for example), the reaction efficiency reached 50 turnovers. Such a reactivity has not yet been reported with other existing amine oxidoreductase model cofactors under similar conditions. [6] In contrast, in the case of isobutylamine, the reaction efficiency did not exceed 8 turnovers, a result in agreement with an untimely deterioration of the catalyst $\mathbf{1}_{\mathbf{o x}}$. Herein, we endeavor to demonstrate that o-azaquinone $\mathbf{1}_{\mathbf{o x}}$ is a willing partner in inverse electron demand Diels-Alder reactions with simultaneously electrogenerated putative enamines (Scheme 2). To the best of our knowledge, this reaction constitutes 
the first example of an intermolecular Diels-Alder reaction[7] of electron-rich dienophiles with an o-quinone imine, though similar reactions with o-quinone monoimides[8] and o-quinone monooximes[9] are known. This unexpected reaction, in which the diene and the dienophile are simultaneously electrogenerated, provides an expeditious route to new polyfunctionalized 1,4-benzoxazine derivatives.

3,4-Iminoquinone $\mathbf{1}_{\text {ox }}$ was electrogenerated from 3,4aminophenol $\mathbf{1}_{\text {red }}$ using anodic-controlled potential electrolysis, at a mercury electrode, in methanol containing an excess of primary aliphatic amine $\mathrm{NH}_{2} \mathrm{CH}_{2} \mathrm{CHR}^{1} \mathrm{R}^{2}$. At a potential for which the 3,4-aminophenol $\mathbf{1}_{\text {red }}$ could be oxidized to the iminoquinone form $\mathbf{1}_{\text {ox }}$ (see Experimental Section), the anodic current remained unchanged for a time, consistent with a steady-state catalytic behavior. This indicated that our catalyst $\mathbf{1}_{\text {ox }}$ was able to oxidize unactivated primary aliphatic amines to the corresponding alkylimines, according to the transamination mechanism reported in Scheme 1.[5] However, the catalytic process ceased after 6 to 8 turnovers. Close inspection of the exhaustively oxidized solution revealed that electrogenerated 3,4-iminoquinone $\mathbf{1}_{\text {ox }}$ was trapped with the tautomeric enamine form of the alkylimine extruded during the catalytic process [Eq. (6), Scheme 1], to give the substituted 1,4-benzoxazine derivatives in good to high yields (52-77\%). Table 1 shows some examples of the molecular diversity accessible through this reaction which constitutes an inverse electron demand controlled DielsAlder reaction between the LUMO of the o-azaquinone heterodiene and the HOMO of the enamine. This uncatalyzed 
cycloaddition reaction occurred at room temperature, in $8 \mathrm{~h}$, with complete regiospecificity, the more electron-rich carbon of the enamine dienophile adding to the nitrogen atom of the heterodiene system $\mathbf{1}_{\text {ox }}$ (Scheme 2). Accordingly, alkylenamines with a pronounced electron-rich character led to the formation of the expected cycloadduct in high yields (entries 1-4), while enamines bearing phenyl substituents afforded somewhat lower yields (entries 5 and 6).

It is noteworthy that no subsequent elimination of the alkylamino chain was observed, in contrast to what has been previously reported for similar cycloadditions of enamines with heterodienes.[10] This feature is of synthetic interest since the methodology we describe represents the first synthesis of 1,4-benzoxazine derivatives bearing alkylamino substituent on the oxazine ring.

In a second series of experiments aimed at increasing the molecular diversity, we attempted to generate enamines whose substituents on the amino group were different from those linked to the double bond. For this purpose, we realized the catalytic oxidation of the amine $\mathrm{R}^{1} \mathrm{R}^{2} \mathrm{CHCH}_{2} \mathrm{NH}_{2}$ by o-azaquinone $\mathbf{1}_{\mathbf{o x}}$, in the presence of another primary aliphatic amine $\mathrm{R}^{3} \mathrm{NH}_{2}$. Table 2 gives some examples of 1,4 benzoxazine derivatives attainable by this process. The choice of amines proved to be important for the outcome of the reaction, the latter being affected by steric and electronic effects exerted by the substituents $R^{1}, R^{2}$ and $\mathrm{R}^{3}$. In particular, the most nucleophilic amine always partook in catalytic oxidation, except when prevented steric hindrance [eq. (2), Scheme 1]. In all cases, both reacting amines were used in equimolecular quantities and no efforts were made to optimize the yield. Further 
investigations would be necessary to establish the reaction conditions leading to the optimal yield.

Finally, the reaction of a separately prepared enamine with the electrogenerated o-azaquinone diene $\mathbf{1}_{\text {ox }}$ was demonstrated in a control experiment. For this purpose, 2,2-diphenylacetaldehyde and 2-methoxyethylamine were condensed to produce the enamine $\mathbf{A}$ (Scheme 3). This was reactive enough to combine with the fairly labile electrogenerated azaquinone $\mathbf{1}_{\mathbf{o x}}$ before its oligomerization, allowing the isolation of the 1,4-benzoxazine derivative 16 in 51\% yield (See Experimental Section). Interestingly, this methodology that uses a separately prepared enamine should expand the scope of the reaction as it would be no longer limited to the enamine part originating from the more nucleophilic amine, as shown in Table 2 .

In summary, we have demonstrated that putative enamines[11] and unstable o-azaquinone $\mathbf{1}_{\mathbf{o x}}$, simultaneously accessible by an electrochemical process, cyclize at room temperature, in the absence of catalyst, with complete regiospecificity, affording in a one-pot operation new polyfunctionalized 1,4-benzoxazine derivatives. Due to their structural similarity with earlier reported 1,4benzoxazines, [4] these compounds could be considered as target structures for the design of novel neuroprotective agents.

Experimental Section

General procedure - Controlled-potential electrolysis was carried out in a cylindrical, three-electrode, divided cell (9 cm diameter), using an electronic potentiostat. In the main compartment, a mercury pool electrode (60 $\mathrm{cm}^{2}$ area) 
served as the anode (working electrode). Note that a platinum grid (6 cm diameter) could be used as the anode, alternatively, except with phenyl substituted aliphatic amines, due to a platinum electrode fouling problem. A platinum sheet was placed in the concentric cathodic compartment (counter electrode), which was separated from the main compartment with a glass frit. The reference electrode was an aqueous saturated calomel electrode (SCE), which was isolated from the bulk solution in a glass tube with a fine-porosity frit. The electrolyte solution [0.02 mol.L-1 tetraethylammonium perchlorate (TEAP) in methanol] was poured into the anodic and the cathodic compartments, as well as into the glass tube that contained the SCE electrode. 3,4-Aminophenol $1_{\text {red }}(0.5 \mathrm{mmol})$ and an excess of primary aliphatic amine $\mathrm{R}^{1} \mathrm{R}^{2} \mathrm{CHCH}_{2} \mathrm{NH}_{2}$ (10 mmol), or a mixture of amine $\mathrm{R}^{1} \mathrm{R}^{2} \mathrm{CHCH}_{2} \mathrm{NH}_{2}$ ( $5 \mathrm{mmol}$ ) and amine $\mathrm{R}^{3} \mathrm{NH}_{2}$ ( 5 mmol), were added to the solution in the main compartment (250 $\mathrm{mL})$, and the resulting solution was then oxidized under nitrogen, at room temperature, at $+50 \mathrm{mV}$ vs SCE (initial current $50 \mathrm{~mA}$ ), i.e. at a potential following the anodic peak observed in cyclic voltammetry, characteristic of the two-electron oxidation of $\mathbf{1}_{\text {red }}$ to $\mathbf{1}_{\mathbf{o x}}$. After exhaustive electrolysis (8-10h, 12 to 16 Faraday.mol-1), i.e., when a negligible value of the current was recorded (1 $\mathrm{mA}$ ), the solution was neutralized with dry ice and the solvent was removed under reduced pressure. The brown oil residue was then poured into diethyl ether $(20 \mathrm{~mL})$. Insoluble TEAP was filtered off and the filtrate was evaporated under reduced pressure, at $30^{\circ} \mathrm{C} . \mathrm{Flash}$ chromatography of the residue on silica gel afforded the expected 1,4-benzoxazine derivative. 
Specific procedure for the synthesis of 16.

Preparation of the enamine $\boldsymbol{A}$ - A mixture of 2,2diphenylacetaldehyde, 2-methoxyethylamine (slight excess), and toluene-p-sulfonic acid (catalytic amount) was heated under reflux in benzene for 18h. The water was removed initially by means of a Dean and Stark separator, followed by a molecular sieve. The solvent was removed under reduced pressure and the residue distilled.

Freshly distilled enamine $\mathbf{A}(2.5 \mathrm{mmol})$ was dissolved in methanol (250 $\mathrm{mL})$ containing TEAP as the supporting electrolyte (5 mmol). 3,4-Aminophenol $1_{\text {red }}(0.5$ mmol) was then added to the resulting solution, along with 2-methoxyethylamine $(0.5 \mathrm{mmol})$. The addition of the latter was necessary to produce the monoanionic species of $\mathbf{1}_{\text {red }}$, which is the sole form oxidizable to o-azaquinone $\mathbf{1}_{\mathbf{o x}}{ }^{[5]}$. The resulting solution was then oxidized, under nitrogen, at room temperature, at a mercury pool whose the potential was fixed at $+50 \mathrm{mV}$ SCE. After exhaustive electrolysis (4h, 2.1 Faraday.mol-1), the solution was treated the same as above (general procedure), leading to the 1,4benzoxazine derivative 16 in 51\% yield.

2. $\mathrm{m} \cdot \mathrm{p} \cdot 133^{\circ} \mathrm{C} ;{ }^{1} \mathrm{H} \operatorname{NMR}\left(300 \mathrm{MHz}, \mathrm{CDCl}_{3}, \mathrm{TMS}\right): \delta=0.85$ (d, $J=6 \mathrm{~Hz}, 3 \mathrm{H}), 0.90(\mathrm{~d}, J=6 \mathrm{~Hz}, 3 \mathrm{H}), 1.25(\mathrm{~s}, 3 \mathrm{H}), 1.30$ $(\mathrm{s}, 3 \mathrm{H}), 1.70(\mathrm{~m}, J=6 \mathrm{~Hz}, 1 \mathrm{H}), 1.90(\mathrm{~s}, 1 \mathrm{H}), 2.50(\mathrm{~m}$, $1 \mathrm{H}), 2.80(\mathrm{~m}, 1 \mathrm{H}), 4.00(\mathrm{~s}, 1 \mathrm{H}), 4.65(\mathrm{~s}, 1 \mathrm{H}), 6.40(\mathrm{~d}, J=$ $9 \mathrm{~Hz}, 1 \mathrm{H}), 7.00(\mathrm{~d}, J=9 \mathrm{~Hz}, 1 \mathrm{H}), 7.50(\mathrm{~m}, 3 \mathrm{H}), 7.65(\mathrm{~m}$, $2 \mathrm{H}), 12.8(\mathrm{~s}, 1 \mathrm{H}) ;{ }^{13} \mathrm{C} \mathrm{NMR}\left(75 \mathrm{MHz}, \mathrm{CDCl}_{3}, \mathrm{TMS}\right): \delta=20.3$, $24.5,26.3,28.8,50.2,53.0,92.9,108.5,112.6,120.9$, $124.0,128.0,128.8,131.2,138.4,146.9,152.0,198.5 ;$ 
$\mathrm{UV} / \mathrm{Vis}$ (methanol) : $\lambda_{\max }(\varepsilon)=258$ (21850), 320 (17150); MS DCI $\mathrm{m} / \mathrm{z}: 355\left[\mathrm{MH}^{+}\right]$.

10. m.p. $110^{\circ} \mathrm{C} ;{ }^{1} \mathrm{H} \operatorname{NMR}\left(300 \mathrm{MHz}, \mathrm{CDCl}_{3}, \mathrm{TMS}\right): \delta=1.25$ (s, $3 \mathrm{H}), 1.30(\mathrm{~s}, 3 \mathrm{H}), 2.10(\mathrm{~s}, 1 \mathrm{H}), 2.90(\mathrm{dd}, J=6 \mathrm{~Hz}$ and $J=13 \mathrm{~Hz}, 1 \mathrm{H}), 3.10(\mathrm{dd}, J=6 \mathrm{~Hz}$ and $J=13 \mathrm{~Hz}, 1 \mathrm{H}), 3.35$ $(\mathrm{s}, 6 \mathrm{H}), 4.00(\mathrm{~s}, 1 \mathrm{H}), 4.45$ ( $\mathrm{t}, \mathrm{J}=6 \mathrm{~Hz}, 1 \mathrm{H}), 4.70$ ( $\mathrm{s}$, $1 \mathrm{H}), 6.40(\mathrm{~d}, J=9 \mathrm{~Hz}, 1 \mathrm{H}), 7.00(\mathrm{~d}, J=9 \mathrm{~Hz}, 1 \mathrm{H}), 7.50$ $(\mathrm{m}, 3 \mathrm{H}), 7.65(\mathrm{~m}, 2 \mathrm{H}), 12.70(\mathrm{~s}, 1 \mathrm{H}) ;{ }^{13} \mathrm{C} \operatorname{NMR}(75 \mathrm{MHz}$ ， $\left.\mathrm{CDCl}_{3}, \mathrm{TMS}\right): \delta=24.5,26.3,47.1,50.2,53.4,54.1,92.5$, 104.2, 108.5, 112.8, 121.0, 123.9, 128.1, 128.9, 131.2, 138.5, 147.1, 152.1, 201.0; UV/Vis (methanol) : $\lambda_{\max }(\varepsilon)=$ $258(21670), 319(17050) ; \operatorname{MS}$ DCI $\mathrm{m} / \mathrm{z}: 387\left[\mathrm{MH}^{+}\right]$.

16. m.p. $190^{\circ} \mathrm{C} ;{ }^{1} \mathrm{H} \operatorname{NMR}\left(300 \mathrm{MHz}, \mathrm{CDCl}_{3}, \mathrm{TMS}\right): \delta=2.50$ (s, $1 \mathrm{H}), 3.00(\mathrm{~m}, 1 \mathrm{H}), 3.10(\mathrm{~m}, 1 \mathrm{H}), 3.20(\mathrm{~s}, 3 \mathrm{H}), 3.35(\mathrm{t}, \mathrm{J}=$ $6 \mathrm{~Hz}, 2 \mathrm{H}), 5.20(\mathrm{~s}, 1 \mathrm{H}), 5.80(\mathrm{~s}, 1 \mathrm{H}), 6.35(\mathrm{~d}, \mathrm{~J}=9 \mathrm{~Hz}$, $1 \mathrm{H}), 6.95(\mathrm{~d}, J=9 \mathrm{~Hz}, 1 \mathrm{H}), 7.20$ to $7.55(\mathrm{~m}, 13 \mathrm{H}), 7.65$ $(\mathrm{m}, 2 \mathrm{H}), 12.90(\mathrm{~s}, 1 \mathrm{H}) ;{ }^{13} \mathrm{C} \mathrm{NMR}\left(75 \mathrm{MHz}, \mathrm{CDCl}_{3}, \mathrm{TMS}\right): \delta=$ $45.0,58.6,62.4,72.6,89.7,108.8,112.8,120.8,124.6$, 126.6, 126.9, 127.0, 128.1, 128.2, 128.4, 128.9, 131.3, 143.0, 144.3, 147.2, 152.3, 200.6; UV/Vis (methanol) : $\lambda_{\max }$ $(\varepsilon)=258(21950), 319(17200) ; \mathrm{MS}$ DCI $\mathrm{m} / \mathrm{z}: 481\left[\mathrm{MH}^{+}\right]$.

\section{References}

[1] Naturally Occurring Quinones IV : Recent Advances, 4th Edition (Ed.: R.H. Thomson), Blackie, London, 1997, p. 746 .

[2] For a recent review on the synthesis of quinones, see W.M. Owton, J. Chem. Soc. Perkin Trans I 1999, 24092420, and references therein.

[3] A.A. Kutyrev, Tetrahedron 1991, 47, 8043-8065. 
[4] a) M. Largeron, M.-B. Fleury, Tetrahedron Lett. 1998, 39, 8999-9002; b) M. Largeron, B. Lockhart, B. Pfeiffer, M.-B. Fleury, J. Med. Chem. 1999, 42, $5043-$ 5052; C) M. Largeron, B. Mesples, P. Gressens, R. Cecchelli, M. Spedding, A. Le Ridant, M.-B. Fleury, Eur. J. Pharmacol. 2001, 424, 189-194.

[5] M. Largeron, M.-B. Fleury, J. Org. Chem. 2000, 65, $8874-8881$.

[6] Recently, the metal ion complex of TTQ model cofactor has been shown to oxidize not only benzylamine but also aliphatic amines in anhydrous organic media, whereas no reaction takes place in the absence of metal ion, see S. Itoh, M. Taniguchi, N. Takada, S. Nagatomo, T. Kitagawa, S. Fukuzumi, J. Am. Chem. Soc. 2000, 122, 12087-12097.

[7] For recent reviews on the hetero Diels-Alder reaction, see a) K.A. Jørgensen, Angew. Chem. 2000, 112, 37023733; Angew. Chem. Int. Ed. Engl. 2000, 39, 3558-3588 and references therein; b) M. Behforouz, M. Ahmadian, Tetrahedron 2000, 56, 5259-5288 and references therein. C) P. Buonora, J.-C. Olsen, T. Oh, Tetrahedron 2001, 57, 6099-6138 and references therein.

[8] a) H.W. Heine, B.J. Barchiesi, E.A. Williams, J. Org. Chem. 1984, 49, 2560-2565; b) H.W. Heine, M.G. La Porte, R. H. Overbaugh, E.A. Williams, Heterocycles 1995, 40, 743-752 and references therein; C) K.C. Nicolaou, Y.L. Zhong, P.S. Baran, Angew. Chem. 2000, 112, 636-639; Angew. Chem. Int. Ed. Engl. 2000, 39, 622-625; d) K.C. Nicolaou, K. Sugita, P.S. Baran, Y.L. 
Zhong, Angew. Chem. 2001, 113, 213-216; Angew. Chem. Int. Ed. Engl. 2001, 40, 207-210.

[9] D.N. Nicolaides, C. Bezergiannidou-Balouctsi, R.W. Awad, K.E. Litinas, E. Malanidou-Xenikaki, A. Terzis, C.P. Raptopoulou, J. Org. Chem. 1997, 62, 499-502 and references therein.

[10]a) G.A. Berchtold, J. Ciabattoni, A.A. Tunick, J. Org. Chem. 1965, 30, 3679-3681; b) S. Danishefsky, R. Cavanaugh, J. Org. Chem. 1968, 33, 2959-2965 and references therein; c) D.L. Boger, Tetrahedron 1983, 39, 2869-2939 and references therein; d) M.S. South, T.L. Jakuboski, M.D. Westmeyer, D.R. Dukesherer, J. Org. Chem. 1996, 61, 8921-8934; e) S. Turchi, R. Nesi, D. Giomi, Tetrahedron, 1998, 54, 1809-1816; f) J. Koyama, I. Toyokumi, K. Tagahara, Chem. Pharm. Bull. 1998, 46, 332-334 and references therein.

[11]It is known that secondary alkylenamines are thermodynamically unstable at room temperature and that the imino-form is the only detectable species. See B. De Jeso, J.-C. Pommier, J. Chem. Soc. Chem. Commun. 1977,565-566 and references therein. 
Legends for Schemes

Scheme 1 - Mechanism of catalytic oxidation of primary aliphatic amines mediated by electrogenerated model quinonoid cofactor $\mathbf{1}_{\mathbf{o x}}$.

Scheme 2 - Diels-Alder reaction of enamine dienophiles with o-azaquinone diene $\mathbf{1}_{\mathbf{o x}}$, simultaneously electrogenerated, leading to polyfunctionalized 1,4-benzoxazine derivatives.

Scheme 3 - Cycloaddition of the separately prepared enamine $\mathbf{A}$ and the electrogenerated o-azaquinone diene $\mathbf{1}_{\mathbf{o x}}$. 
Table 1. Inverse electron demand Diels-Alder reactions of simultaneously electrogenerated diene and enamine dienophile. Yields of 1,4-benzoxazine derivatives 2-7.<smiles>[R]C([R])=CN(CC([R])[R])CC([R])CNC1Oc2ccc(C(=O)c3ccccc3)c(O)c2NC1([R])[R]</smiles>

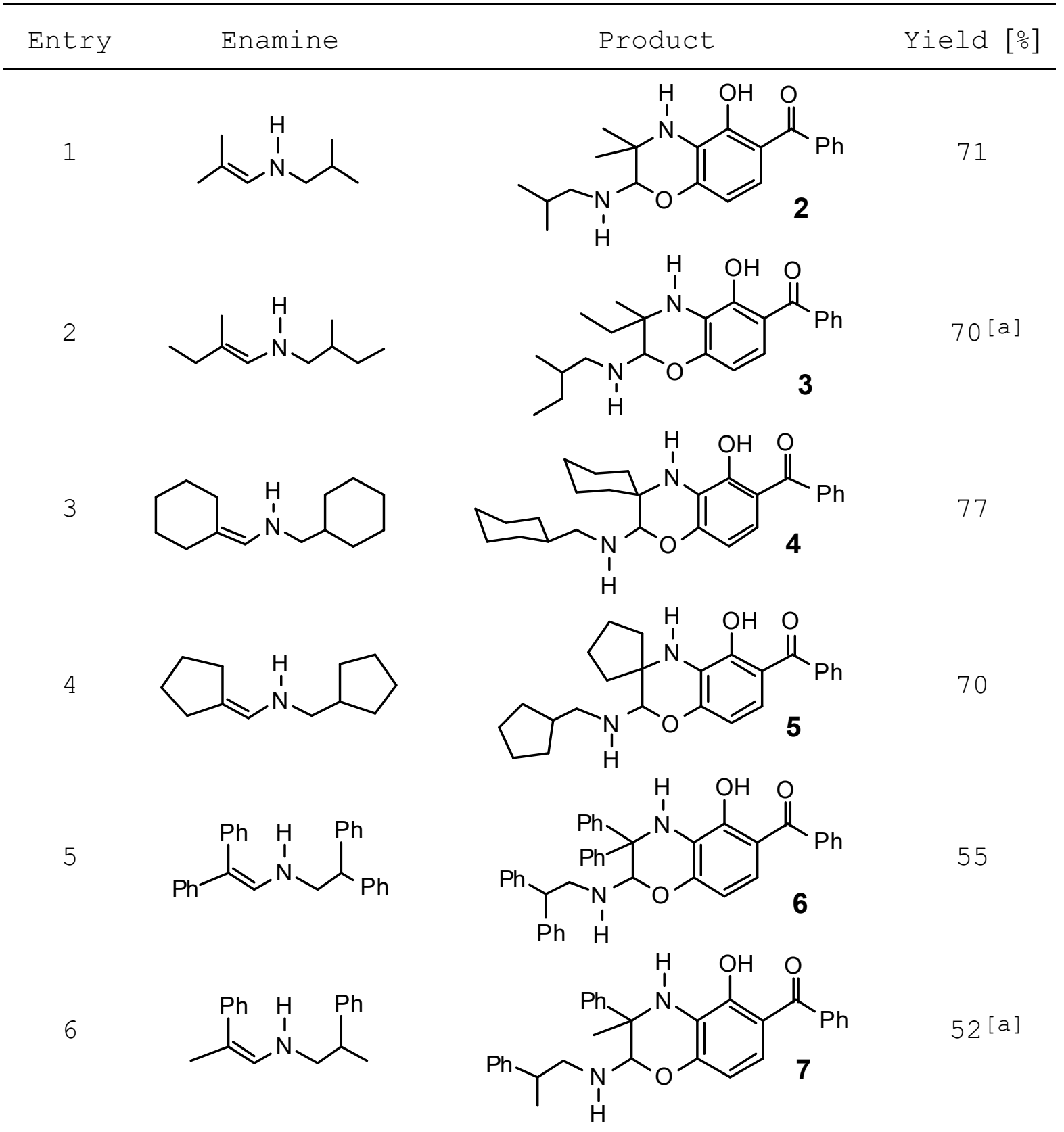

[a] This product was obtained as a mixture of two unassigned diastereoisomers (ca. 1:1 ratio). 
Table 2. Catalytic oxidation of amine $\mathrm{R}^{1} \mathrm{R}^{2} \mathrm{CHCH}_{2} \mathrm{NH}_{2}$ by oquinone imine $\mathbf{1}_{\mathbf{o x}}$, in the presence of a second amine $\mathrm{R}^{3} \mathrm{NH}_{2}$. Yields of 1,4-benzoxazine derivatives 8-15.<smiles>[2H]C1=C(C(=O)c2ccccc2)C=CC(=O)C1=N</smiles><smiles>[R]C([R])=CNNC</smiles>

$\mathrm{MeOH}, 25^{\circ} \mathrm{C}$<smiles>[R]NC1Oc2ccc(C(=O)c3ccccc3)c(O[13CH2])c2NC1([R])[R]</smiles><smiles>CCCC(C)=CN(CC(OC)OC)CC(OC)OC</smiles> 
[a] This product was obtained as a mixture of two unassigned diastereoisomers (ca. 1:1 ratio). [b] Beside benzoxazines 10, 14 and 15, benzoxazines $\mathbf{2}, \mathbf{3}$ and $\mathbf{4}$ were isolated as the minor products, in 5, 10 and 20\% yields, respectively. 


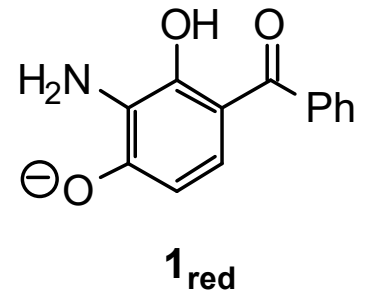

$\underset{1)}{\stackrel{-2 e-H^{+}}{\longrightarrow}}$<smiles>N=C1C(=O)C=CC(C(=O)c2ccccc2)=C1O</smiles>

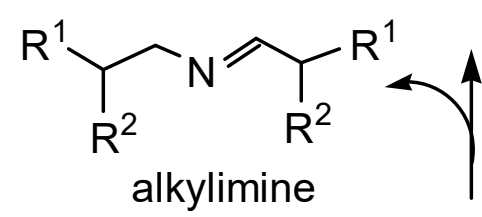

6)<smiles>[R]C([R])CNC(Nc1c(O)ccc(C(=O)c2ccccc2)c1O)C([R])[R]</smiles><smiles>[R]C([R])CNC1(N)C(=O)C=CC(C(=O)c2ccccc2)=C1O</smiles><smiles>[R]C([R])CN</smiles><smiles>[R]C([R])C=Nc1c(O)ccc(C(=O)c2ccccc2)c1O</smiles><smiles>[PH3+]C1CC1CC1CC1</smiles>

3) $\underset{\downarrow}{\longrightarrow} \mathrm{NH}_{3}$ 


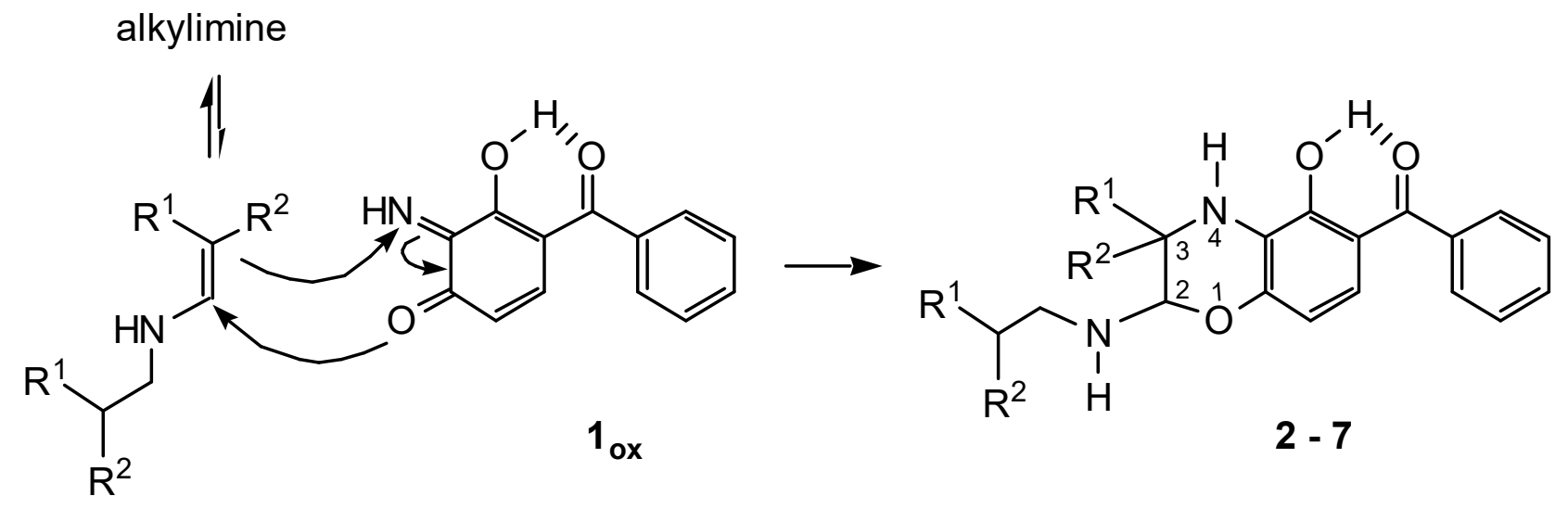

Scheme 2 
$\overbrace{\mathrm{O}}^{\mathrm{Ph}}+\mathrm{H}_{2} \mathrm{~N} \sim \sim^{\mathrm{OMe}}$

benzene $\bigsqcup_{\downarrow}$ reflux/8 h<smiles>COCCNC=C(c1ccccc1)c1ccccc1</smiles>

A

Scheme 3 
Short text for the table of contents

An

unprecedented

regiospecific

cycloaddition

of simultaneously electrogenerated o-quinone imine and highly reactive enamine can be performed, at ambient temperature, in the absence of catalyst. This reaction, which constitutes a powerful tool for the one-pot synthesis of new polyfunctionalized 1,4-benzoxazine derivatives, gives an insight into molecular entities attainable with electrogenerated quinonoid systems.<smiles>N=C1C(=O)C=CC(C(=O)c2ccccc2)=C1[18OH]</smiles><smiles>[R]NC=C([R])[R]</smiles><smiles>[R]NC1Oc2ccc(C(=O)c3ccccc3)c(O[2H])c2N([R])C1([R])[R]</smiles>

Keywords : cofactors, cycloaddition, electrochemistry, nitrogen heterocycles, quinones. 